\title{
Inequalities in infant mortality among municipalities in Brazil according to the Family Development Index, 2006-2008
}

\author{
Walter Massa Ramalho, ${ }^{1}$ Luciana Monteiro Vasconcelos Sardinha, ${ }^{2}$ \\ Isabela Pereira Rodrigues, ${ }^{3}$ and Elisabeth Carmen Duarte ${ }^{1}$
}

$\begin{array}{ll}\text { Suggested citation } & \text { Ramalho WM, Sardinha LMV, Rodrigues IP, Duarte EC. Inequalities in infant mortality among munici- } \\ \text { palities in Brazil according to the Family Development Index, 2006-2008. Rev Panam Salud Publica. }\end{array}$ palities in Brazil acc

\begin{abstract}
Objective. To describe inequalities in the infant mortality rate (IMR) according to socioeconomic indicators among geographic areas and municipalities in Brazil.

Methods. This was an exploratory ecological study of space aggregates that described IMR in 2006-2008 according to municipalities, states, and the Family Development Index (FDI), a socioeconomic indicator that ranges from 0 to 1. All the municipalities in Brazil were categorized according to four strata as defined by FDI quartiles, where stratum 4 included those with better FDI conditions, and stratum 1, worse conditions. The selected inequality measures were: Concentration Index, Attributable Risk Percent, Population Attributable Risk Percent, Rate Ratio, and number of avoidable events (number of infant deaths).

Results. The average IMR (per 1000 live births) according to the FDI strata were: stratum $1(F D I=0.41-0.52)=18.8 ;$ stratum $2(F D I=0.53-0.55)=17.9 ;$ stratum $3(F D I=$ $0.56-0.58)=15.0$; and stratum $4(F D I=0.59-0.73)=13.4$. Overall, the Concentration Index was 0.02. Moreover, stratum 1, with a proportion of $17 \%$ of all live births in the population, had a concentration of $20 \%$ of infant deaths. Additionally, the profile of causes and ages of infant mortality also differed qualitatively when stratum 1 was compared to stratum 4.

Conclusions. The results suggest an association between the socioeconomic indicators, specifically the FDI, and the risk of infant death. These results call attention to the specific population groups in Brazil that are most vulnerable to infant mortality and demonstrate that the FDI can be used to identify these populations.
\end{abstract}

Key words Health inequalities; infant mortality; infant mortality rate; infant welfare; Brazil.

Social inequalities and inequities have been repeatedly approached in the current literature (1). Natural inequalities, in contrast to social inequalities, result from biological differences among indi-

\footnotetext{
${ }^{1}$ Universidade de Brasília, Brasília, Brasil. Send correspondence to Walter Massa Ramalho, email: walterramalho@unb.br

${ }^{2}$ Ministério da Saúde, Secretaria de Vigilância em Saúde, Brasília, Brasil.

${ }^{3}$ Hospital Universitário da Universidade de Brasília, Brasília, Brasil.
}

viduals, i.e., differences such as sex, ethnicity, and age. These differences do not necessarily determine social inequalities, except when used by society as a criterion by which to attribute social roles (2). Social inequality implies the unequal distribution of tangible and intangible goods and services among socially distinct groups.

The distribution of health can also be influenced by inequalities. Inequalities in access to goods and services, and differences in health behaviors and risk factors, can be determined by an individual's position in society $(3,4)$. Moreover, a certain subtype of health inequality is rooted in unfairness and characterized by social injustice-this is known as health inequity (5). Health inequity is an ethical problem that affects a society $(5,6)$. One study in particular further defines this inequity as unnecessary and preventable, in addition to being unfair (7). As such, health inequity is of great 
importance to public policy, representing an expression of social injustice and an opportunity for public health action. To identify a certain inequality as an "inequity" means to recognize its causes and to quantify the injustice produced by these causes at a given time in history within a particular society $(7,8)$.

Analysis of Infant Mortality Rate (IMR) distribution among the socially distinct groups of a given area can permit hypotheses to be drawn about this indicator's preventability and any social injustice that may exist (9-13). In addition, in Brazil, the Ministério de Desenvolvimento Social e Combate a Fome (Ministry of Social Development and the Fight Against Hunger; MDS) in partnership with the Instituto de Pesquisa Econômica Aplicada (Institute for Applied Economic Research; IPEA) developed the Family Development Index (FDI), a composite indicator to measure the degree of socioeconomic development of families registered in the Cadastramento Único para Programas Sociais do Governo Federal (Unified Registry System for Federal Government Social Programs; CADUNICO) $(14,15)$.

The present study sought to describe the distribution of IMR in Brazil according to socioeconomic indicators. Inequalities in infant mortality risk among all municipalities for the period from 2006-2008 were evaluated according to the FDI for the year 2007.

\section{MATERIALS AND METHODS}

This was an exploratory, ecological study with spatial clusters that described the magnitude of inequality in infant mortality risk, measured by the IMR, according to municipality, state, geographic area, and quartile as designated by the FDI.

This study included all of the municipalities in Brazil as units of analysis. The following exclusion criteria were adopted: i) municipalities that did not report any infant deaths during the 3-year period from 2006-2008; and, ii) municipalities that did not include any families registered with CADUNICO in 2007 (15). Either of these conditions would have limited data analysis since the IMR and/or FDI would not have been calculable.

The study used only public, secondary data without name identification to maintain participant anonymity.

\section{Analysis indicators}

Infant Mortality Rate (IMR). IMRs, by state, were obtained from the 2008 Basic Indicators of the Interagency Health Information Network $(13,16)$. The IMRs, by municipality, were calculated with the 2006, 2007, and 2008 data, obtained directly from the online database of Ministry of Health of Brazil: Sistema de Informações sobre Mortalidade (Information System on Mortality; SIM) (16) and Sistema de Informações sobre Nascidos Vivos (Information System on Live Births; SINASC) (16).

\section{Proportional infant mortality by cause} and age. The proportions of infant deaths by cause and age ( $<7$ days, 7 to $<28$ days, and 28 days to $<1$ year of age) were estimated for each of the four strata of analysis.

Family Development Index (FDI). The FDI is a composite indicator developed in 2003 to measure the level to which a family's basic needs are being met (15). It aims to quantify the family's degree of vulnerability from 0 (worst living conditions) to 1 (best living conditions) based on six components briefly described as follows:

1. Family vulnerability, including the presence/absence of child, adolescent, and young members, and physical and/or socially handicapped members;

2. Access to knowledge, including level of literacy (or illiteracy) and formal education;

3. Access to employment, including unemployment, employment without salary, and income of the head of household;

4. Availability of financial resources, measured by poverty (family income per capita above the poverty line);

5. Infant and young child development, including child labor, education access and performance, and child mortality; and,

6. Housing conditions, including number of inhabitants, access to goods and services, including sanitation services.

FDI data in this study was based on the families registered in CADUNICO in 2007. All municipalities were placed into one of four strata determined by FDI quartiles, stratum 1 having the worst
FDI conditions, and stratum 4, the best. Stratum 4 was used as a reference for comparisons (17).

Structure indicators. The Sistema de Informação da Atenção Básica (Primary Health Care Information System; SIAB) enabled the characterization of municipality strata according to the structure indicators selected: SIAB coverage; percentages of households with public water service, garbage collection, public sewage service, or electricity; and percentage of homes built with bricks (16).

\section{Data analysis}

The following indicators of inequalities were used for each study municipality: Concentration Index (CI), Attributable Risk Percent (ARP), Population Attributable Risk Percent (PARP), Rate Ratio (RR), and Number of Preventable Events (preventable infant deaths per strata and total preventable infant mortality).

In addition, concentration curves and box plots were used to show the distribution and concentration of infant deaths or IMR of municipalities according to strata defined by FDI quartiles. Municipalities were ordered according to their FDI in the concentrations curves, and the proportions of their infant deaths and live births were accumulated until reaching $100 \%$, as previously described (8). These proportions shown in the graph define a curve. The calculation of the area under the curve represents the concentration index, ranging from 0 (perfectly equitable distribution of events) to 1 (total concentration of events) (18-20).

A map of Brazil was used for the spatial representation of municipality strata according to FDI quartiles. The chi-square test was used to analyze the statistical significance of differences in proportional infant mortality by cause and age, considering the comparison between a certain stratum and stratum 4 ; the significance level was set at 0.05 .

\section{RESULTS}

The IMR estimated for Brazil in 2006 was 20.6 deaths per 1000 live births (LB) (Figure 1). The state with the lowest risk of infant death was Santa Catarina, with 12.5 deaths per $1000 \mathrm{LB}$; the state with the highest was Alagoas with 42.7. The risk of infant mortality in Alagoas was 3 

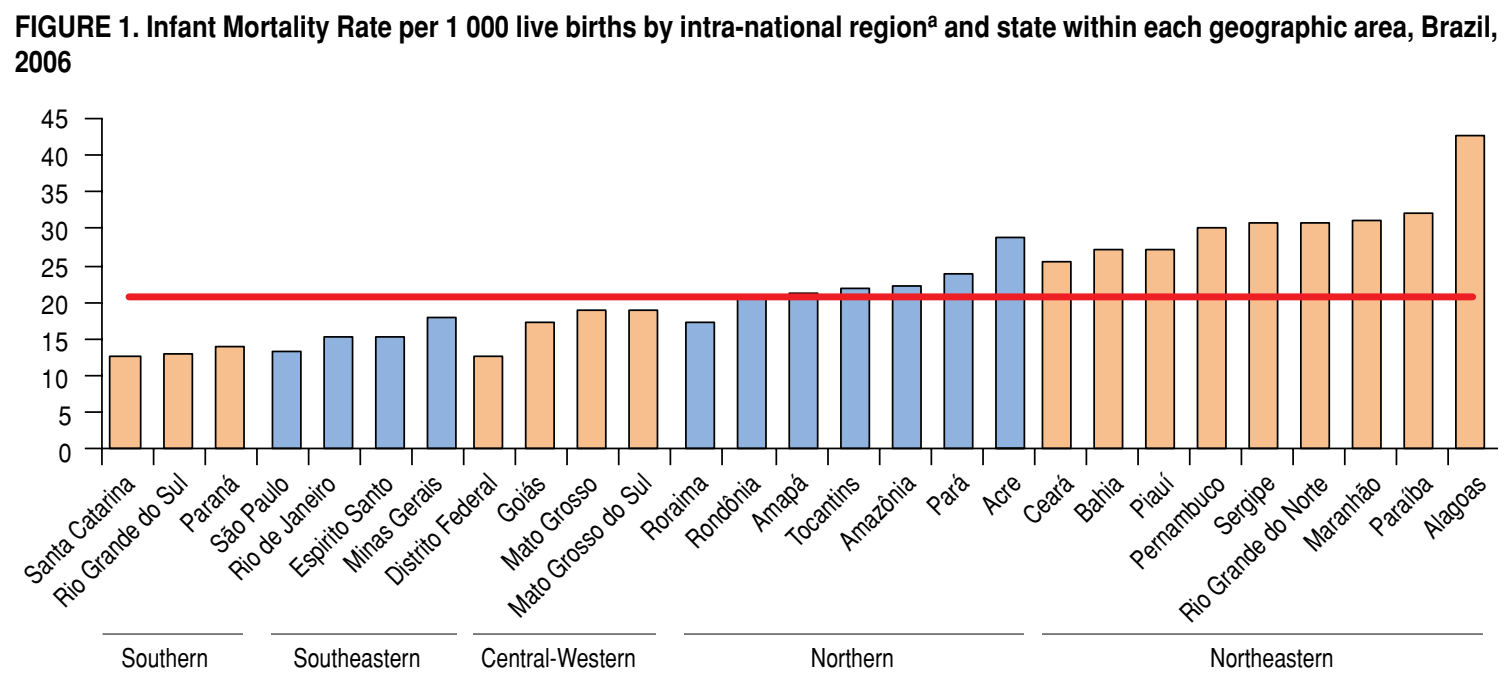

The red line represents the mean IMR value for Brazil, 20.6 per 1000 live births.

times higher (Risk Ratio $[R R]=3.4$ ) than in Santa Catarina in 2006. In general, the IMRs of the Southern, Southeastern, and Central-Western part of Brazil were much lower than those of the Northern and Northeastern, where almost all states have rates higher than the national mean value.

A total of 5227 (94\%; total = 5564) Brazilian municipalities were included in the analysis by municipality. The municipalities studied were grouped into FDI quartiles: stratum $1=$ FDI of 0.41-0.52 (1 685 municipalities); stratum $2=0.53-0.55$ (1 128); stratum $3=0.56-0.58$ (1 085); and, stratum $4=0.59-0.73$ (1 329) (Table 1). The municipalities grouped in strata 1 and 2 are primarily distributed in the Northern and Northeastern areas, also including northern Minas Gerais state and the western Central-Western area (Figure 2). On the other hand, the municipalities grouped in strata 3 and 4 are mainly distributed in the Southern and Southeastern areas of Brazil.

The results point to a variation in IMR among the four strata, from 18.8 deaths per $1000 \mathrm{LB}$ (stratum 1, worst FDI) to 13.4 deaths per 1000 LB (stratum 4, best FDI) (Table 1 and Figure 3A). The municipalities with the worst FDI (stratum 1) had an excess of 5.3 deaths per 1000 LB, representing $28.5 \%$ of the IMR in this stratum (Table 1). This represents approximately 9700 infant deaths that could be prevented if infant mortality in these stratum 1 municipalities were the same as in stratum 4 (reference). Finally, nearly 19300 infant deaths could be prevented in Brazil if infant mortality in all municipalities were equal to stratum 4 municipalities (reference), totaling a reduction of $14 \%$. It should also be noted

that there is a wide dispersion of IMR distribution among municipalities in all four strata (Figure 3A).

TABLE 1. Indicators selected from the municipality strata according to the Family Development Index (FDI) quartiles, Brazil, 2006-2008

\begin{tabular}{|c|c|c|c|c|}
\hline Indicator & Stratum 1 & Stratum 2 & Stratum 3 & Stratum 4 \\
\hline \multicolumn{5}{|l|}{ Demographic indicators } \\
\hline Number of municipalities & 1685 & 1128 & 1085 & 1329 \\
\hline Live births (LB) & 1814494 & 1350512 & 2228309 & 3324987 \\
\hline Infant deaths & 34079 & 24167 & 33526 & 44674 \\
\hline \multicolumn{5}{|l|}{ Infant Mortality Rate per } \\
\hline 1000 LB & 18.8 & 17.9 & 15.0 & 13.4 \\
\hline FDI (range) & $0.49(0.41-0.52)$ & $0.53(0.53-0.55)$ & $0.57(0.56-0.58)$ & $0.61(0.59-0.73)$ \\
\hline \multicolumn{5}{|l|}{ Structure indicators ${ }^{a}$} \\
\hline Coverage $^{b}$ & 95.9 & 95.8 & 85.8 & 78.9 \\
\hline $\begin{array}{l}\text { Percent of homes with pub } \\
\text { water system }\end{array}$ & 42.7 & 57.5 & 60.0 & 63.9 \\
\hline $\begin{array}{l}\text { Percent of homes with } \\
\text { garbage collection }\end{array}$ & 35.1 & 51.6 & 60.7 & 66.0 \\
\hline $\begin{array}{l}\text { Percent of homes with pub } \\
\text { sewage system }\end{array}$ & 8.4 & 17.8 & 25.8 & 36.2 \\
\hline $\begin{array}{l}\text { Percent of homes built of } \\
\text { bricks }\end{array}$ & 63.5 & 78.5 & 65.5 & 61.9 \\
\hline $\begin{array}{l}\text { Percent of homes with } \\
\text { electricity }\end{array}$ & 72.8 & 84.9 & 82.1 & 77.2 \\
\hline \multicolumn{5}{|l|}{ Inequality indicators ${ }^{c}$} \\
\hline Rate ratios & 1.4 & 1.3 & 1.1 & Reference \\
\hline $\begin{array}{l}\text { Differences in rates } \\
\text { (per } 1000 \text { LB) }\end{array}$ & 5.3 & 4.5 & 1.6 & Reference \\
\hline $\begin{array}{l}\text { Attributable risk percent } \\
\text { (\% of IMR) }\end{array}$ & 28.5 & 24.9 & 10.7 & Reference \\
\hline $\begin{array}{l}\text { Preventable events (numb } \\
\text { of infant deaths) }\end{array}$ & 9699.8 & 6021.7 & 3586.8 & Reference \\
\hline \multicolumn{5}{|l|}{ Overall inequality indicators } \\
\hline \multicolumn{4}{|c|}{ Population Attributable risk (stratum 4 as the reference group): } & $14.1 \%$ \\
\hline \multicolumn{4}{|c|}{ Concentration Index } & 0.02 \\
\hline \multicolumn{4}{|c|}{ Total number of preventable events (infant deaths)(stratum 4 as the reference group): } & 19308 \\
\hline
\end{tabular}

a Estimated from the Sistema de Informação da Atenção Básica (Primary Health Care Information System; SIAB) maintained by the Ministry of Health.

b Proportion of individuals assisted by Sistema Único de Saúde (SUS) in December 2007.

${ }^{c}$ Inequality indicators: IMR from stratum 4 was used as reference group. 
FIGURE 2. Spatial distribution of municipalities grouped according Family Development Index (FDI) quartile, Brazil, 2006-2008

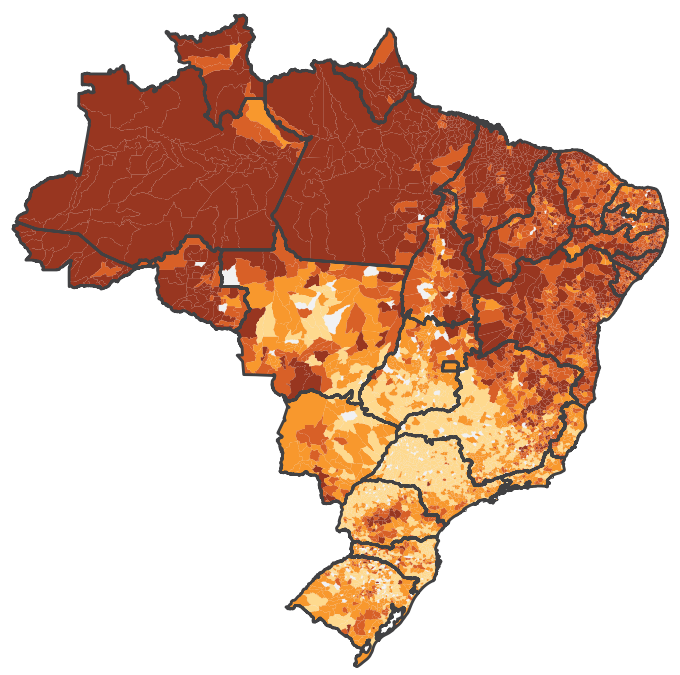

Stratum 1 municipalities are mostly small and better covered by the Family Health Program and Community Health Agents (part of the Primary Health Care Strategy strongly supported by SUS) than stratum 4 municipalities. In contrast, better structure indicators-percentages of homes with water and sewage system and garbage collection-are observed in stratum 4, when compared to stratum 1 (Table 1).

The result of the Concentration Index obtained for the IMR distribution (20062008) by FDI in Brazilian municipalities was 0.02 (Table 1). This value indicates the proportion $(0.2 \%)$ that corresponds

FIGURE 3A. Inequality in the Infant Mortality Rate (IMR) by median and quartiles according to the Family Development Index (FDI) of municipalities, Brazil, 2006-2008

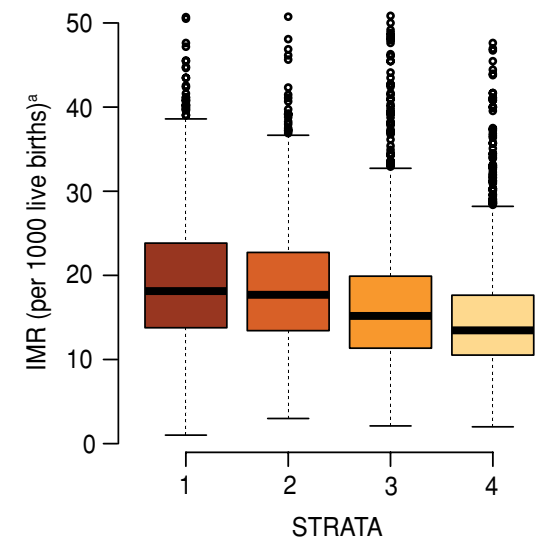

a Ordinate axis limited to IMR $=50$ per 1000 live births.
Strata defined by FDI quartile

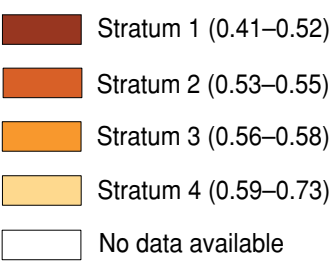

were concentrated in $17 \%$ of the live births occurring in municipalities with the worst FDI that comprise stratum 1 (Figure 3B). In contrast, stratum 4 municipalities, which show the best FDI conditions, accumulated only $31 \%$ of all infant deaths in $36 \%$ of live births in Brazil.

Proportional infant mortality by cause and age were also analyzed (Table 2). Researchers observed that the higher the FDI (from stratum 1 to stratum 4), the greater the statistical significance $(P<0.001)$ of the representativeness of external causes $(1.2 \%-2.8 \%$, respectively) and of congenital malformation and chromosomal abnormalities $(13.4 \%-21.0 \%$, respectively) as causes of infant mortality; and the lower the representativeness of blood, immunological, metabolic, and nutritional diseases $(4.1 \%-1.2 \%$, respectively), respiratory diseases $(7.8 \%-5.2 \%$, respectively), and infectious and parasitic diseases $(10.0 \%-4.0 \%$, respectively).

Additionally, there was a statistically significant reduction $(P<0.001)$ in the representativeness of post-neonatal deaths (28 days to $<1$ year), from $36.0 \%$ $30.8 \%$ with the increase in FDI from stratum 1 to stratum 4 , respectively, and the resulting increase in representativeness of neonatal deaths (especially from 7 to

3B. Inequality in the Infant Mortality Rate (IMR) by Concentration Curve ${ }^{\mathrm{a}}$ : proportion of infant deaths per live births (LB) in municipalities categorized by the Family Development Index (FDI), Brazil, 2006-2008

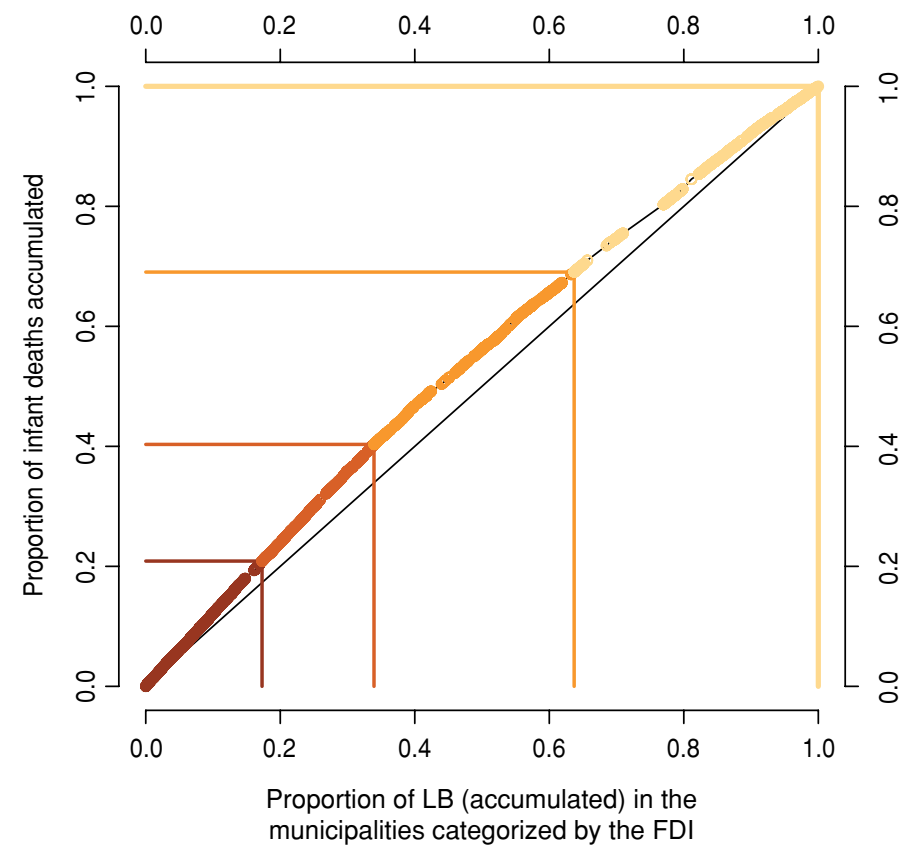

a Area under the curve (Concentration Index) $=0.02$; horizontal and vertical lines delimit the strata of cities defined by FDI quartiles. 
TABLE 2. Proportional infant mortality by cause and age in the strata of municipalities defined by quartile according to the Family Development Index (FDI), Brazil, 2006-2008

\begin{tabular}{|c|c|c|c|c|c|c|c|c|c|c|c|}
\hline \multirow[b]{2}{*}{$\begin{array}{l}\text { Proportional } \\
\text { infant mortality }\end{array}$} & \multicolumn{3}{|c|}{$\begin{array}{c}\text { Stratum } 1 \\
(\mathrm{FDI}=0.41-0.52)\end{array}$} & \multicolumn{3}{|c|}{$\begin{array}{c}\text { Stratum } 2 \\
(\mathrm{FDI}=0.53-0.55)\end{array}$} & \multicolumn{3}{|c|}{$\begin{array}{c}\text { Stratum } 3 \\
(\mathrm{FDI}=0.56-0.58)\end{array}$} & \multicolumn{2}{|c|}{$\begin{array}{l}\text { Stratum } 4 \text { (reference) } \\
(\mathrm{FDI}=0.59-0.73)\end{array}$} \\
\hline & $\begin{array}{l}\text { Number } \\
\text { of deaths }\end{array}$ & $\%$ & $P$ value ${ }^{a}$ & $\begin{array}{l}\text { Number } \\
\text { of deaths }\end{array}$ & $\%$ & $P$ value ${ }^{a}$ & $\begin{array}{l}\text { Number } \\
\text { of deaths }\end{array}$ & $\%$ & $P$ value $^{\mathrm{a}}$ & $\begin{array}{l}\text { Number } \\
\text { of deaths }\end{array}$ & $\%$ \\
\hline \multicolumn{12}{|l|}{ By group of causes } \\
\hline External causes & 331 & 1.2 & $<0.001$ & 402 & 1.6 & $<0.001$ & 1086 & 2.7 & 0.998 & 1158 & 2.8 \\
\hline \multicolumn{12}{|l|}{$\begin{array}{l}\text { Blood, immunological, } \\
\text { nutritional, and metabolic }\end{array}$} \\
\hline Infectious and parasitic & 2647 & 10.0 & $<0.001$ & 2048 & 8.0 & $<0.001$ & 1815 & 4.8 & $<0.001$ & 1636 & 4.0 \\
\hline $\begin{array}{l}\text { Congenital malformations and } \\
\text { chromosomal abnormalities }\end{array}$ & 3535 & 13.4 & $<0.001$ & 3878 & 15.2 & $<0.001$ & 7302 & 19.2 & $<0.001$ & 8577 & 21.0 \\
\hline Perinatal diseases & 15724 & 59.6 & $<0.001$ & 15874 & 62.2 & 0.090 & 23475 & 61.8 & 0.411 & 24989 & 61.2 \\
\hline Other causes & 1019 & 3.9 & 0.001 & 1007 & 4.0 & 0.009 & 1583 & 4.2 & 0.166 & 1835 & 4.5 \\
\hline \multicolumn{12}{|l|}{ By age } \\
\hline
\end{tabular}

a Proportional infant mortality from stratum 4 was used as reference group for all hypotheses tested in each category.

$<28$ days of life) from $12.8 \%-18.1 \%$ from stratum 1 to stratum 4 , respectively.

\section{DISCUSSION}

Overall, health care and socioeconomic contexts are associated with premature deaths. While the quality and coverage of the health care system seem crucial to preventing infant deaths, socioeconomic determinants certainly also play an important role in how health care may impact infant mortality. The present study suggests a strong relationship between the FDI and infant mortality indicators. A greater concentration of infant deaths was found in municipalities with the lowest FDI; moreover, the profile of causes and ages of infant mortality in these strata also differed qualitatively from reference stratum 4.

\section{Importance of infant mortality}

Worldwide, infant mortality has been considered a primary indicator of development. Its importance was underscored by the United Nations' (UN) Millennium Development Goals (MDG), a commitment made by member countries in 2000 . The 4th goal of MDG is to reduce mortality among children under 5 years of age by two-thirds from 1990-2015, especially infant mortality since it contributes most to the indicator (21).

Infant death is an event that is extremely premature and preventable, in most cases by low-complexity actions in the areas of health, education, and urban development. Thus, these deaths are events sensitive or vulnerable to public policies aimed at and implemented in different social contexts. Additionally, to monitor social inequalities in the risk of disease and death, especially in the first year of life, encourages one to reflect on the injustices observed among distinct social groups and to generate explanatory hypotheses for the health-disease process as a result of social phenomena.

\section{The Brazilian context and the problem}

In recent decades, Brazil has experienced improvements in social indicators and in health services quality and coverage. The IMR, in particular, has decreased by almost $62 \%$, from 52.0 per $1000 \mathrm{LB}$ in 1990 to 19.9 per $1000 \mathrm{LB}$ in $2010(13,22)$. With regard to mortality rates among children less than 5 years of age, based on the trend currently observed, the Ministry of Health of predicts that the 4th MDG will be achieved in Brazil prior to the UN deadline of 2015 $(21,23)$. Fertility rate reductions, improved living conditions, expanded access to quality health goods and services, and sector policies in the area of education are important elements in Brazil's downward trending IMR (16). However, despite the apparently positive results of the last 30 years, the current IMR in Brazil is mainly the result of preventable causes, strongly associated with low socioeconomic conditions and comparable to that of developed countries in the 1960 s $(24,25)$. At this time, the IMR is approximately 3-4 times higher than that of the United States (6.7 per 1000 LB in 2007) and Canada (5.0) (26). According to a recent study, in 2010 Brazil was still in 90th place in the world for this indicator, well behind other developing countries with similar economic conditions, e.g., Mexico (16.5 per 1000 LB), China (15.4), Colombia (15.3), Argentina (12.8), Chile (6.5) and Cuba (5.3) (25).

In addition, in Brazil, the probability of premature death in the first year of life persists with a highly unequal distribution by population subgroups, whether they are defined geographically or by socioeconomic characteristics. The present study points out, for instance, that only 12 states had an IMR lower than the national mean value (20.6 deaths per 1000 LB) in 2006, and this indicator varies greatly among states, ranging from values higher than 40 deaths per 1000 LB (in Alagoas) to lower than 14 in others (Rio Grande do Sul, Santa Catarina, and São Paulo).

\section{IMR according to FDI}

The FDI is a proxy of socioeconomic indicators that are gaining attention as putative determinants of population health and, particularly, early deaths in Brazil. Despite limitations inherent to the use 
of FDI to estimate socioeconomic level, it was observed that strata 1 and 2 included the municipalities with the worst FDI (least favorable living conditions as measured by access to water service, garbage collection, and a sewage system) and higher risk of infant mortality, compared to stratum 4 whose FDI conditions were most favorable.

\section{IMR according to space}

With regard to the spatial distribution of infant deaths, the present study showed that these events have a very asymmetrical distribution across the country, whether considering the various sub-national regions, the states within a certain sub-national region, or the municipalities within a particular state. The Southern and Southeastern sub-national region showed the lowest risks of infant death, whereas the Northern and Northeastern ones showed the highest. Differences in living conditions and health care have been repeatedly pointed out in the literature as reasons for such contrasts $(7,11,12)$.

The estimated state data indicate that all Northeastern and Northern states, except for Roraima, have IMRs higher than the national mean value. Even Alagoas and Paraíba have a risk of infant death 3 times higher than that reported for Santa Catarina in 2006. Additionally, when the 3-year period IMR is analyzed by municipality, there was a significant variation in this indicator in the rural areas of the states.

In general, it can be affirmed that, despite observed improvements in mean IMR values, high rates persist in certain geographic areas, states, and municipalities with adverse health care and living conditions. These high rates contradict the level of development attained by most of Brazil. Methodologies that identify a municipality's areas of risk and any determining factors-including any associated with health care services-can help develop policies aimed at specific populations and their level of vulnerability.

\section{IMR according to age}

Inequalities in IMR associated with living conditions are even more significant in the post-neonatal component (28 days to $<1$ year), since they more directly reflect infrastructure issues, i.e., access to an adequate sewage system, mother's education, and housing conditions. Health promotion and specific disease prevention actions, such as immunizations and sewage service, have been reported to be closely associated with reductions and/or stabilization of this IMR component by other studies conducted in Brazil $(27,28)$.

\section{IMR according to causes}

The present study also describes important differences between the proportions of infant deaths by causes in the different strata. As an example, greater representativeness of infections and parasitic diseases was reported in the stratum of municipalities with the worst FDI (10\%, stratum 1), compared to the one with the best FDI (4\%, stratum 4). Most of the time, the causes of infant deaths can be prevented with lowcomplexity health service actions, i.e., primary care that includes immunizations; early, quality prenatal care; and access to adequate diagnosis and treatment of diarrheal diseases, among others (29-31).

Comparing the relevant contribution of infectious and parasitic diseases to infant mortality in the less-developed municipalities of Brazil to the almost complete eradication of such diseases in more developed areas prompts one to consider the possibility that the SUS has been implemented to different degrees in different areas. In the context of the Ministry of Health, reduction of infant mortality in the Northeast and the Legal Amazon areas was one of four priorities established by the federal government as part of a strategy to diminish geographic inequalities in the Brazil. Mobilization of the government society as a whole and the individual citizen are important to consolidating this reduction and moving toward the prevention of premature deaths (32). Finally, the impact of these policies must be monitored.

\section{Study limitations}

The present study has certain limitations that must be discussed, especially those associated with the use of secondary data. The information about socioeconomic and demographic conditions in Brazil's municipalities is usually updated during census periods exclusively, which could limit its validity for inter-census periods. As a result, researchers decided to use data originating from the Ministry of Social Development's CADUNICO program, including the FDI. Thus, the municipalities where no families had registered with CADUNICO were excluded. Also excluded were municipalities that did not report infant deaths during the 3-year period (2006-2008). This could have resulted from the lack of infant deaths in small populations and/or underreporting of deaths to the Information System on Mortality. Municipalities excluded on the basis of this criterion were mainly certain municipalities in the Northeastern and Northern areas, and could have had an influence on IMR estimates and time trends (33).

These methodological options for excluding municipalities could have caused a certain (artificial) homogeneity among study municipalities and the loss of statistical significance in certain comparisons. However, the possibility of selection bias due to the two exclusion criteria was ignored in the present study in light of the broad representativeness of eligible municipalities (5 227 or $94 \%$ ) compared to the total number of municipalities (5 561 in 2000). Finally, the FDI is estimated according to the low-income households in each municipality, per the CADUNICO database. The use of this index as an indicator that estimates the socioeconomic conditions of municipalities must be validated in future studies, although the present study indicated reproducibility and plausibility in the analyses described.

The present study's findings allow recommendations to be made that focus on infant mortality prevention actions in low-income municipalities. Additionally, future studies will be able to assess FDI validity as a proxy measure of a municipality's vulnerability in other contexts.

\section{Conclusions}

The present study showed inequalities in the risk of infant death according to spatial distribution and socioeconomic indicators-estimated with the FDI-in an ecological analysis of Brazilian municipalities in 2007. The results suggest an association between the FDI and the risk of infant mortality. The greater concentration of infant deaths in municipalities with worse FDI conditions, found 
mainly in the less developed areas of Brazil (the Northeastern and Northern), provides evidence of an association between socioeconomic conditions and the risk of infant mortality. Although such conclusions are not new, they call attention to the specific population groups in Brazil that are most vulnerable to infant mortality and demonstrate that the FDI can be used to identify these populations.

Acknowledgements. The authors thank professors Elza Souza and Gilvânia Feijó of the University of Brasilia, and students Danielle Kaiser, Max Sarmet, and Ricardo Jacarandá de Faria, for their invaluable contributions during the lecture debates of the study's methodology and results.

\section{Conflicts of interest. None}

\section{REFERENCES}

1. Avendano M. Correlation or causation? Income inequality and infant mortality in fixed effects models in the period 1960-2008 in 34 OECD countries. Soc Sci Med. 2012;75(4): 754-60.

2. Wilkinson RG, Pickett KE. Income inequality and population health: a review and explanation of the evidence. Soc Sci Med. 2006;62(7):1768-84.

3. Messer LC. Invited commentary: measuring social disparities in health-what was the question again? Am J Epidemiol. 2008;167(8):900-4.

4. Kumanyika S. Health disparities research in global perspective: new insights and new directions. Annu Rev Public Health. 2012;33(1):1-5

5. Starfield B. State of the art in research on equity in health. J Health Polit Policy Law. 2006;31(1):11-32.

6. Whitehead M. The concepts and principles of equity and health. Int $\mathrm{J}$ Health Serv. 1992;22(3):429-45

7. Starfield B. Equity and health: a perspective on nonrandom distribution of health in the population. Rev Panam Salud Publica. 2002;12(6):384-7.

8. Schneider MC, Castillo-Salgado C, Bacallao J, Loyola E, Mujica OJ, Vidaurre M, et al. Métodos de medición de las desigualdades de salud. Rev Panam Salud Publica. 2002;12(6):398-414.

9. Goldani MZ, Barbieri MA, Bettiol H, Barbieri MR, Tomkins A. Infant mortality rates according to socioeconomic status in a Brazilian city. Rev Saude Publica. 2001;35(3):256-61.

10. Weightman AL, Morgan HE, Shepherd MA, Kitcher H, Roberts C, Dunstan FD. Social inequality and infant health in the UK: systematic review and meta-analyses. BMJ Open. 2012;2(3):e000964.

11. Fischer TK, Lima D, Rosa R, Osório D, Boing AF. A mortalidade infantil no Brasil: série histórica entre 1994-2004 e associação com indicadores socioeconômicos em municípios de médio e grande porte. Medicina (Ribeirão Preto). 2007:40(4):559-66.

12. Grant J. Situação mundial da infância, 1993. Brasília: Fundo das Nações Unidas para a Infância; 1992

13. Ministério da Saúde (Brasil), Departamento de Informática do Sistema Único de Saúde. Indicadores e dados básicos para a saúde da Rede Interagencial de Informações para a Saúde, 2009. Available from http://tabnet. datasus.gov.br/cgi/idb2009/matriz.htm Accessed on 12 December 2012

14. Barros, RP, Carvalho, M, Franco, S. O índice de desenvolvimento da famíia (IDF). Vol 986. IPEA, 2003

15. Ministério do Desenvolvimento Social (Brasil). Índice de desenvolvimento da família. Available from http://www.mds.gov. $\mathrm{br} /$ falemds/perguntas-frequentes/bolsafamilia/cadastro-unico/gestor/cadunicoindice-de-desenvolvimento-da-familia-idf Accessed on 9 December 2012.

16. Ministério da Saúde (Brasil), Departamento de Informática do Sistema Único de SaúdeSUS (DATASUS). Available from http:// www2.datasus.gov.br/DATASUS/index. php?area $=0205$ Accessed on 12 December 2012.

17. Duarte ED, Schneider MC, Paes-Sousa R, Silva JB, Castillo-Salgado C. Expectativa de vida ao nascer e mortalidade no Brasil em 1999: análise exploratória dos diferenciais regionais. Rev Panam Salud Publica. 2002;12(6):436-44.

18. Kakwani NC, A. Wagstaff, E. van Doorslaer. Socioeconomic inequalities in health: measurement, computation and statistical inference. J Econom. 1997;77(1):87-104.

19. Mackenbach JP, Kunst AE. Measuring the magnitude of socio-economic inequalities in health: an overview of available measures illustrated with two examples from Europe. Soc Sci Med. 1997;44:757-71.

20. Wagstaff A, Paci P, Van Doorslaer E. On the measurement of inequalities in health. Soc Sci Med. 1991;33:545-57.

21. United Nations Development Program. Human Development Report 2003. Millennium Development Goals: A contract among nations to end human poverty. New York: UNDP; 2003.

22. Victora CG, Aquino EM, do Carmo Leal M, Monteiro CA, Barros FC, Szwarcwald CL. Maternal and child health in Brazil: progress and challenges. Lancet. 2011;377(9780): 1863-76.

23. Escalante JJC, Morais Neto OL. A redução da mortalidade na infância e infantil no Brasil e nas unidades da federação In: Ministério da Saúde, editor. Saúde Brasil 2008. Brasília: Ministério da Saúde; 2010. Pp. 177-200.

24. Boing AF, Boing AC. Mortalidade infantil por causas evitáveis no Brasil: um estudo ecológico no período 2000-2002. Cad Saude Publica. 2008;24(2):447-55.
25. Rajaratnam JK, Marcus JR, Flaxman AD, Wang $\mathrm{H}$, Levin-Rector A, Dwyer L, et al. Neonatal postneonatal, childhood, and under-5 mortality for 187 countries, 1970-2010: a systematic analysis of progress towards Millennium Development Goal 4. Lancet. 2010;375(9730): 1988-2008.

26. Pan American Health Organization. Health situation in the Americas, 2009. Available from http://new.paho.org/hq/dmdocuments/ 2009/BI_ENG_2009.pdf Accessed on 28 November 2012.

27. Leal MC, Szwarcwald CL. Evolução da mortalidade neonatal no Estado do Rio de Janeiro, Brasil (1979 a 1993): análise por causa segundo grupo de idade e região de residência. Cad Saude Publica. 1996;12:243-52.

28. Souza RTS, Gotlieb SLD. Probabilidade de morrer no primeiro ano de vida em área urbana da Região Sul, Brasil. Rev Saude Publica. 1993;27:445-543.

29. Gomes FAR, Araújo Júnior AF, Salvato MA. Mortalidade infantil no Brasil e Sudeste: determinantes e perspectivas para o futuro. In: XV Encontro Nacional de Estudos Populacionais. Ibmec MG Working Paper-WP36. Caxambú, 2006. Available from http:// www.abep.nepo.unicamp.br/encontro2006/ docspdf/ABEP2006 653.pdf Accessed on 15 November 2012.

30. Malta DC, Duarte EC. Causas de mortes evitáveis por ações efetivas dos serviços de saúde: uma revisão da literatura. Cien Saude Colet. 2007;12(3):765-76.

31. Malta DC, Duarte EC, Almeida MF, Dias MAS, Morais Neto OL, Moura L, et al. Lista de causas de mortes evitáveis por intervenções do Sistema Unico de Saúde do Brasil. Rev Epid Serv Saude. 2007;16(4):233-44.

32. Ministério da Saúde, Secretaria de Atenção à Saúde, Departamento de Análise de Situação de Saúde, Brasil. Manual de vigilância do óbito infantil e fetal e do comitê de prevenção do óbito infantil e fetal. Brasília: Ministério da Saúde; 2009.

33. Szwarcwald CL, Leal MC, Andrade CLT, Borges PRSJ. Estimação da mortalidade infantil no Brasil: o que dizem as informações sobre óbitos e nascimentos do Ministério da Saúde? Cad Saude Publica. 2002;18:1725-36.

Manuscript received on 10 May 2012. Revised version accepted for publication on 4 January 2013. 
RESUMEN Objetivo. Describir las desigualdades en la tasa de mortalidad de menores de un año entre las zonas geográficas y los municipios del Brasil según los indicadores socioeconómicos.

Desigualdades en la Métodos. Se realizó un estudio exploratorio y ecológico de los grupos de espacios mortalidad de menores de un que definieron la tasa de mortalidad de menores de un año en el período de 2006 a 2008 según los municipios, los estados y el índice de desarrollo familiar (IDF), un indicador socioeconómico que va del 0 al 1 . Todos los municipios del Brasil se clasificaron según 4 estratos, de conformidad con lo definido por los cuartiles del IDF; el estrato 4 incluyó a aquellas personas con mejores condiciones de IDF y el estrato 1 a aquellas con peores condiciones. Se eligieron las siguientes medidas de la desigualdad: el índice de concentración, el porcentaje de riesgo atribuible a la población, la razón de la tasa y el número de sucesos evitables (número de defunciones de menores de un año). Resultados. La tasa promedio de mortalidad de menores de un año (por 1000 nacidos vivos) según los estratos del IDF fueron: estrato 1 (IDF $=0,41-0,52)=18,8$; estrato $2(\mathrm{IDF}=0,53-0,55)=17,9$; estrato $3(\mathrm{IDF}=0,56-0,58)=15,0$; y estrato 4 $(\mathrm{IDF}=0,59-0,73)=13,4$. En términos generales, el índice de concentración fue 0,02. Al estrato 1, que tuvo una proporción de $17 \%$ de todos los nacidos vivos en la población, correspondió una concentración de $20 \%$ de defunciones de menores de un año. Además, el perfil de las causas y las edades de la mortalidad de menores de un año también difirió cualitativamente cuando se compararon los estratos 1 y 4 .

Conclusiones. Los resultados indican que hay una asociación entre los indicadores socioeconómicos, en concreto el IDF, y el riesgo de mortalidad de menores de un año. Estos resultados destacan los grupos de población específicos en el Brasil que son más vulnerables a la mortalidad de menores de un año y demuestran que el IDF puede utilizarse para identificarlos.

Palabras clave Desigualdades en la salud; mortalidad infantil; tasa de mortalidad infantil; bienestar del lactante; Brasil. 